\title{
Membangun Kepatuhan Perpajakan Sejak Dini Melalui Workshop Pengisian SPT PPh Orang Pribadi di SMKN 10 Jakarta
}

\author{
Selvi ${ }^{1}$, Notika Rahmi ${ }^{2}$, Pebriana Arimbhi ${ }^{3}$ \\ Institut Ilmu Sosial dan Manajemen STIAMI, Jakarta, Indonesia 1,2,3 \\ selvi300990@gmail.com,notika.rahmi@gmail.com, pebrianasusanto@yahoo.co.id
}

ARTICLE INFO

Keywords:

Tax Compliance

Personal Income Tax

Return

\section{ABSTRACT}

Tax is the largest source of state income. However, people's complianc with paying taxes is still low. Therefore, tax education is needed early on. Th research question in this activity is how to calculate and fill in the Persona Income Tax Return. The method of this activity is by lecture, demonstratio: and practice of calculating income tax and filling in the Personal Income Ta. Return at SMKN 10 Jakarta. Conclusion of this activity Workshop Completioi of Personal Income Tax Return can be held well and run smoothl Participants are able to manually calculate and record the Personal Incom Tax Return. The shortcomings are the absence of learning media, namel. dummy e-filing to be practiced by participants

\section{A. PENDAHULUAN}

Pajak merupakan sumber pendapatan negara terbesar $70 \%$ APBN didanai dari pajak. Hal ini sejalan dengan salah satu fungsi pajak yakni fungsi budgetair dimana pajak berfungsi untuk menghimpun dana masyarakat yang kemudian akan digunakan untuk membiayai keperluan negara.

Menurut Djadjadiningrat yang dikutip dari (Resmi, 2017, p. 1) "Pajak sebagai suatu kewajiban menyerahkan sebagian dari kekayaan ke kas negara yang disebabkan suatu keadaan, kejadian, dan perbuatan yang memberikan kedudukan tertentu, tetapi bukan sebagai hukuman, menurut peraturan yang ditetapkan pemerintah serta dapat dipaksakan, tetapi tidak ada timbal balik dari negara secara langsung untuk memelihara kesejahteraan secara umum".Sementara Menurut Andiriani yang dikutip dari (Pohan, 2014) "Pajak adalah iuran masyarakat kepada negara (yang dipaksakan) yang terutang oleh yang wajib membayarnya menurut peraturan-peraturan umum (undang-undang) dengan tidak mendapat prestasi kembali yang langsung dapat ditunjuk dan yang gunanya adalah untuk membiayai pengeluaran-pengeluaran umum berhubungan tugas negara untuk menyelenggarakan pemerintahan". Dengan salah satu sifat pajak yang tidak memberikan kontraprestasi /imbalan secara langsung kepada pembayarnya, membuat masih rendahnya kesadaran masyarakat untuk taat pajak kerana masyarat masih belum merasakan dampak pembayaran pajak secara nyata.

Pemerintah melakukan berbagai cara guna meningkatkan kesadaran dan kepatuhan masyarakat yang salah satu nya ialah dengan Program Inklusi Kesadaran Pajak. Pemerintah melalui Program Inklusi Kesadaran Pajak menerapkan kegiatan Pajak Bertutur guna menggali potensi penerimaan melalui sektor pajak dengan meningkatkan pemahaman Wajib Pajak terhadap sistem pajak melalui edukasi perpajakan yang terstruktur sejak dini kepada generasi muda.

Tingkat kepatuhan masyarakat Indonesia memang sudah semakin membaik, hal ini dibuktikan dengan adanya pertumbuhan pada penyampaian Surat Pemberitahuan Tahunan Pajak Penghasilan hingga 31 Maret 2018 telah masuk sebanyak 10,59 juta SPT, atau naik 14\% dibandingkan periode yang sama di tahun sebelumnya yaitu tahun 2017. Namun hal tersebut masih harus terus ditingkatkan agar semakin banyak masyarakat yang sadar dengan kewajibannya ebagai wajib pajak. Program pemerintah berupa inklusi kesadaran pajak, diupayakan untuk merubah paradigma membayar pajak di masyarakat. Agar masyarakat tidak merasa terbebani ketika membayar pajak, DJP berupaya merubah paradigma tersebut menjadi bangga membayar pajak sebagai bentuk kontribusi untuk negeri. 
Kepatuhan menurut Nurmantu dalam (Rahayu, 2010, p. 139) dijelaskan sebagai berikut: "Kepatuhan perpajakan dapat didefinisikan sebagai suatu keadaaan dimana Wajib Pajak memenuhi semua kewajiban perpajakan dan melaksanakan hak perpajakannya”. Sementara itu definisi kepatuhan menurut kamus besar bahasa Indonesia dalam (Rahayu, 2010, p. 138) adalah: "Istilah kepatuhan berarti tunduk atau patuh pada ajaran atau aturan. Dalam perpajakan kita dapat memberi pengertian bahwa Kepatuhan Perpajakan merupakan ketaatan, tunduk dan patuh serta melaksanakan ketentuan pajak." Kepatuhan ada dua macam jenis, menurut (Rahayu, 2010, p. 138) kepatuhan pajak dibagi menjadi kepatuhan formal dan kepatuhan material. Kepatuhan formal adalah suatu keadaan dimana Wajib Pajak memenuhi kewajiban secara formal sesuai dengan ketentuan dalam Undang-undang Perpajakan. Misalnya ketentuan batas waktu penyampaian Surat Pemberitahuan Pajak Penghasilan (SPT Pph) Tahunan tanggal 31 Maret. Apabila Wajib Pajak telah melaporkan Surat Pemberitahuan Pajak Penghasilan (SPT Pph) Tahunan sebelum atau pada tanggal 31 Maret. Kepatuhan material adalah suatu keadaan dimana Wajib Pajak secara substantif atau hakekatnya memenuhi semua ketentuan material perpajakan, yakni sesuai isi dan jiwa Undang-undang Perpajakan. Kepatuhan material dapat juga meliputi kepatuhan formal. Wajib Pajak yang memenuhi kepatuhan material adalah Wajib Pajak yang mengisi dengan jujur, lengkap, dan benar Surat Pemberitahuan (SPT) sesuai ketentuan dan menyampaikannya ke KPP sebelum batas waktu berakhir.

Berdasarkan studi pendahuluan yang telah kami lakukan pada siswa/siswi tingkat SMA/SMK, kami ajukan pertanyaan terkait pentingnya melapor dan membayar pajak ternyata 10 dari 30 siswa/siswi belum memahami pentingnya melapor dan membayar pajak. Institut Ilmu Sosial dan Manajemen STIAMI merupakan salah satu kampus pajak di Jakarta mencoba membantu pemerintah untuk memberikan edukasi pajak ke sekolah-sekolah. Adapun kegiatan yang dilakukan adalah dengan memberikan workshop aplikatif kepada siswa/siswi SMK yang lulusannya diharapkan siap kerja dan siap untuk melaksanakan kewajiban perpajakan. Workshop ini berisikan tentang tata cara penghitungan Pajak Penghasilan Orang Pribadi Pasal 21 yakni PPh Orang Pribadi yang penghasilannya berasal dari pemberi kerja yang akan dilanjutkan dengan pengisian SPT.

Menurut (Cansavera, 2009, p. 7): "Surat Pemberitahuan adalah surat yang digunakan oleh Wajib Pajak untuk melaporkan penghitungan dan/atau bukan objek pajak dan/atau harta dan kewajiban sesuai dengan ketentuan peraturan perundang-undangan perpajakan". Berikut ini adalah fungsi surat pemberitahuan menurut (Mardiasmo, 2011, p. 31):

1. Bagi Wajib Pajak

Adalah sebagai sarana untuk melaporkan dan mempertanggungjawabkan perhitungan jumlah pajak yang sebenarnya terutang dan untuk melaporkan tentang:

a. Pembayaran atau pelunasan pajak yang telah dilaksanakan sendiri dan/atau melalui pemotongan atau pemungutan pihak lain dalam 1 Tahun Pajak atau Bagian Tahun Pajak.

b. Penghasilan yang merupakan objek pajak dan/atau bukan objek pajak.

c. Harta dan kewajiban.

d. Pembayaran dari pemotongan atau pemungut tentang pemotongan atau pemungutan pajak orang pribadi atau badan lain dalam 1 Masa Pajak sesuai dengan ketentuan peraturan perundang-undangan perpajakan.

2. Bagi Pengusaha Kena Pajak

Adalah sebagai sarana untuk melaporkan dan mempertanggungjawabkan penghitungan jumlah Pajak Pertambahan Nilai dan Pajak Penjualan atas Barang Mewah yang sebenanya terutang dan untuk melaporkan tentang:

a. Pengkreditan Pajak Masukan terhadap Pajak Keluaran.

b. Pembayaran atau pelunasan pajak yang telah dilaksanakan sendiri oleh Pengusaha Kena Pajak dan/atau melalui pihak lain dalam satu Masa Pajak, sesuai dengan ketentuan peraturan perundang-undangan perpajakan.

3. Bagi Pemotong Atau Pemungut Pajak

Sebagai sarana untuk melaporkan melaporkan dan mempertanggungjawabkan pajak yang dipotong atau dipungut dan disetorkannya.

Perumusan masalah dalam kegiatan ini ialah bagaimana langkah penghitungan dan pengisian SPT PPh Orang Pribadi. Adapun tujuan kegiatan ini ialah untuk memberikan 
pengetahuan kepada siswa/siswi dalam melakukan penghitungan dan pengisian SPT PPh Orang Pribadi. Manfaat workshop ini ialah:

a. Memberikan pemahaman tentang pentingnya pajak bagi kehidupan berbangsa dan bernegara yang berujung pada tumbuhnya kesadaran dan kepatuhan perpajakan di kalangan siswa

b. Memberikan pelatihan penghitungan hingga pengisian SPT PPh Orang Pribadi Pasal 21 yang diharapkan akan menjadi bekal di dunia kerja

\section{B. PELAKSANAAN DAN METODE}

Khalayak sasaran kegiatan workshop ini ialah siswa/siswi kelas XII SMKN 10 Jakarta sejumlah 72 orang. Adapun kegiatan dilaksanakan di Auditorium SMKN 10 Jakarta Jl. Mayjen Soetoyo, Cawang, Kramat Jati - Jakarta Timur.

Narasumber workshop ini ialah:

1. Selvi., S.AP., MA

2. Notika Rahmi., S.AP., MA

3. Pebriana Arimbhi., S.Sos., M.Si

Agar workshop berjalan lancar dan mencapai target tujuan yang telah dirumuskan, maka workshop ini dilakukan dengan melalui pendekatan klasikal dan individual. Pendekatan klasikal dilakukan pada saat pemberian teori tentang pajak penghasilan sedangkan pendekatan individual dilakukan pada saat demonstrasi pengisian SPT PPh Orang Pribadi.

Adapun metode yang dilakukan:

1. Ceramah

Metode ini dipilih untuk menyampaikan konsep-konsep yang penting untuk dimengerti dan dikuasai oleh peserta pelatihan. Adapun konsep yang disampaikan berupa dasar-dasar perpajakan serta dasar-dasar Pajak Penghasilan.

2. Demonstrasi

Metode ini dipilih untuk menunjukkan suatu proses kerja yaitutahap-tahap penghitungan dan pengisian SPT PPh Orang Pribadi. Adapun demonstrasi dilakukan dengan menggunakan SPT manual

3. Latihan

Metode ini digunakan untuk memberikan tugas kepada peserta untuk mempraktikkan penghitungan dan pengisian SPT PPh Orang Pribadi

Adapun langkah-langkah kegiatan ini ialah:

1. Ceramah tentang pengantar perpajakan

2. Ceramah tentang dasar-dasar Pajak Penghasilan

3. Demonstrasi penghitungan dan pengisian SPT PPh Orang Pribadi

4. Latihan penghitungan dan pengisian SPT PPh Orang Pribadi

Faktor Pendukung

a. Siswa/siswi SMKN 10 sudah memiliki dasar pengetahuan pajak yang cukup baik

b. Antusiasme siswa yang sangat baik untuk mengikuti kegiatan workshop

c. Dukungan guru dan kepala sekolah

Faktor Penghambat

Keterbatasan media pembelajaran berupa pengisian SPT secara $e$-filing dikarenakan belum ada dummy sehingga membutuhkan data Wajib Pajak yang sebenarnya

\section{HASIL DAN PEMBAHASAN}

Kegiatan workshop yang dilaksanakan dengan acara tatap muka dan praktek berjalan dengan baik dan lancar. Pertemuan tatap muka dengan metode ceramah dan demonstrasi dilanjutkan dengan 
latihan untuk melakukan penghitungan dan pengisian SPT PPh Orang Pribadi. Kegiatan ini dilakukan pada 15 November 2018 mulai pukul 08.00-16.00 WIB. Peserta kegiatan berjumlah 72 orang siswa/siswi SMKN 10 Jakarta.

Dalam pelaksanaan workshop ini, materi yang disampaikan adalah sebagai berikut:

1. Dasar-dasar perpajakan

Narasumber memberikan informasi mengenai Pengertian Pajak, dimana pajak merupakan iurang wajib yang dibayarkan oleh rakyat kepada negara dengan tidak mendapat imbalan secara langsung berdasarkan Undang-undang dan dapat dipaksakan, yang digunakan untuk membiayai pengeluaran negara demi sebesar-besarnya kemakmuran rakyat. Narasumber juga memberikan informasi mengenai istilah-istilah yang sering digunakan dalam dunia perpajakan seperti, WP adalah Wajib pajak, SPT adalah Surat Pemberitahuan, KPP adalah Kantor Pelayanan Pajak, NPWP adalah Nomor Pokok Wajib Pajak, dan sebagainya. Peserta workshop juga diberikan informasi mengenai pentingnya membayar pajak dan uang yang telah dibayarkan wajib pajak kepada negara digunakan untuk berbagai hal seperti sektor pembangunan, kesehatan, pendidikan, kesejahteraan masyarakat dan masih banyak lagi.

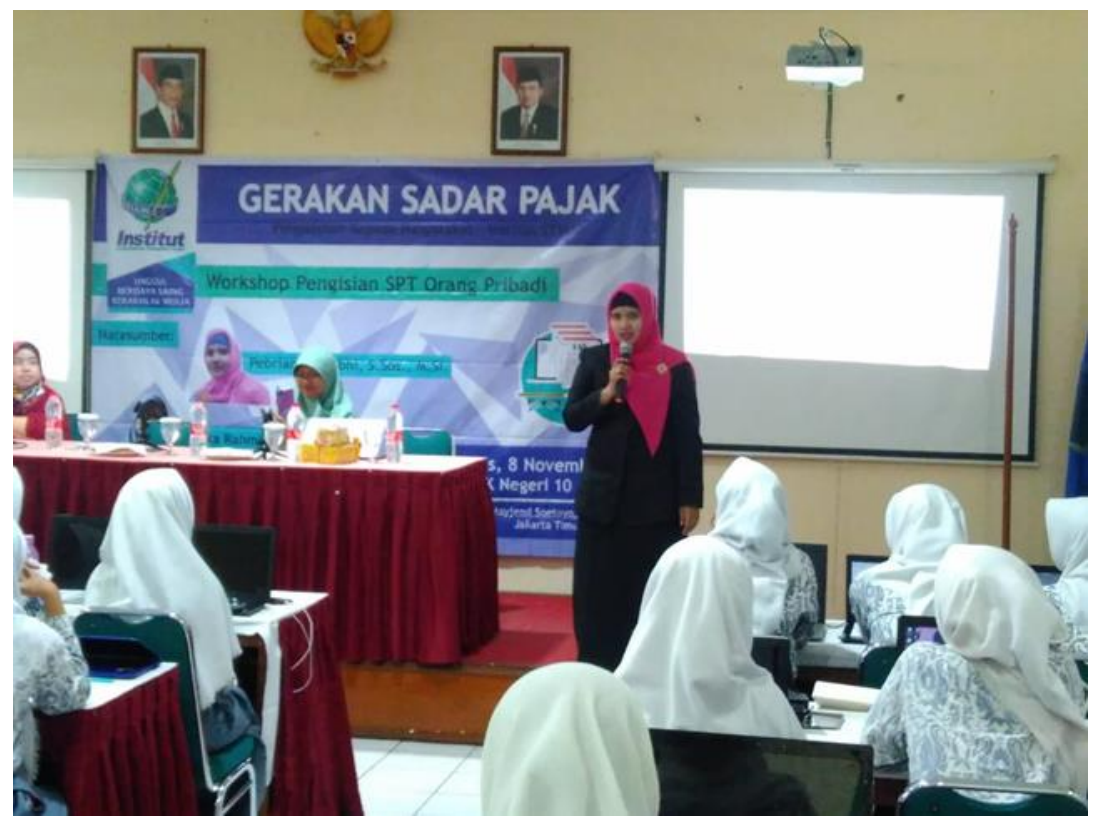

Gambar 1. Penyampaian Materi Pengantar Perpajakan oleh Pebriana Arimbhi, S.Sos., M.Si.

2. Dasar-dasar Pajak Penghasilan

Indonesia menganut sistem pemungutan pajak berupa self asessment system dimana wajib pajak yang menghitung, menyetor dan melapokan sendiri pajaknya. Sehingga diperlukan pengetahuan yang cukup untuk mengaplikasikan sistem tersebut. Narasumber memberikan informasi mengenai Pajak Penghasilan seperti; Subjek Pajak Penghasilan yang artinya orang pribadi atau badan yang ditetapkan oleh peraturan perundang-undangan yang berlaku. Objek pajak adalah setiap penghasilan yang diterima atau diperoleh wajib pajak. Narasumber juga memberikan informasi mengenai tarif yang digunakan untuk menghitung pajak penghasilan orang pribadi, serta batasan penghasilan tidak kena pajak (PTKP) untuk wajib pajak dengan berbagai status keluarga. 


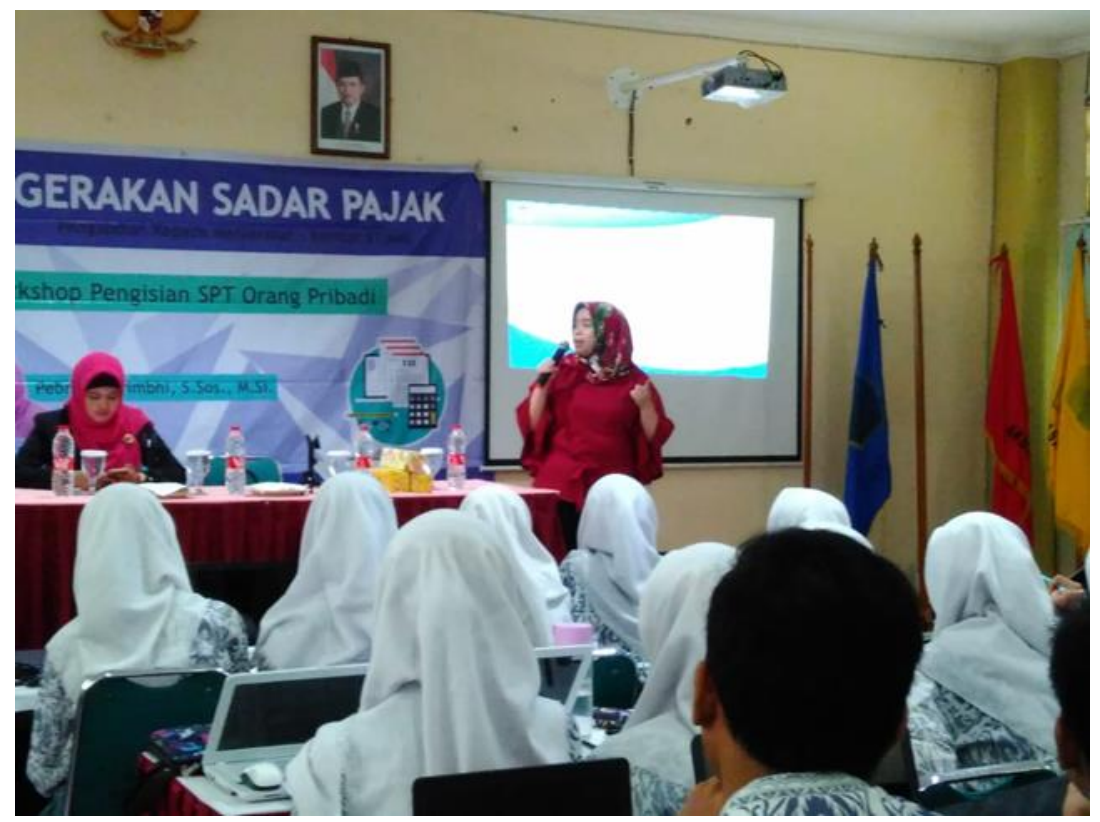

Gambar 2. Penyampaian Materi Dasar-dasar dan Penghitungan Pajak Penghasilan oleh Selvi, S.AP., MA.

3. Demonstrasi Penghitungan dan Pengisian SPT PPh Orang Pribadi

Narasumber memberikan contoh soal untuk dibahas bersama dalam mencari pajak terutang yang akan disetor dan dilaporkan oleh wajib pajak orang pribadi. Selanjutnya data yang telah dihitung di masukkan kedalam SPT Tahunan Orang Pribadi. SPT Tahunan Orang Pribadi terdiri dari 3 jenis, yaitu SPT 1770 SS yang diperuntukkan kepada kasryawan dari 1 pemberi kerja dan penghasilan brutonya dalam satu tahun pajak tidak lebih dari 60 juta rupiah, SPT $1770 \mathrm{~S}$ diperuntukkan bagi karyawan yang bekerja di satu atau lebih dari satu perusahaan dan memiliki penghasilan bruto dalam satu tahun pajak diatas 60 juta rupiah, dan yang terakhit SPT 1770 diperuntukkan bagi orang pribadi yang memiliki usaha atau menjalankan usaha bebas.

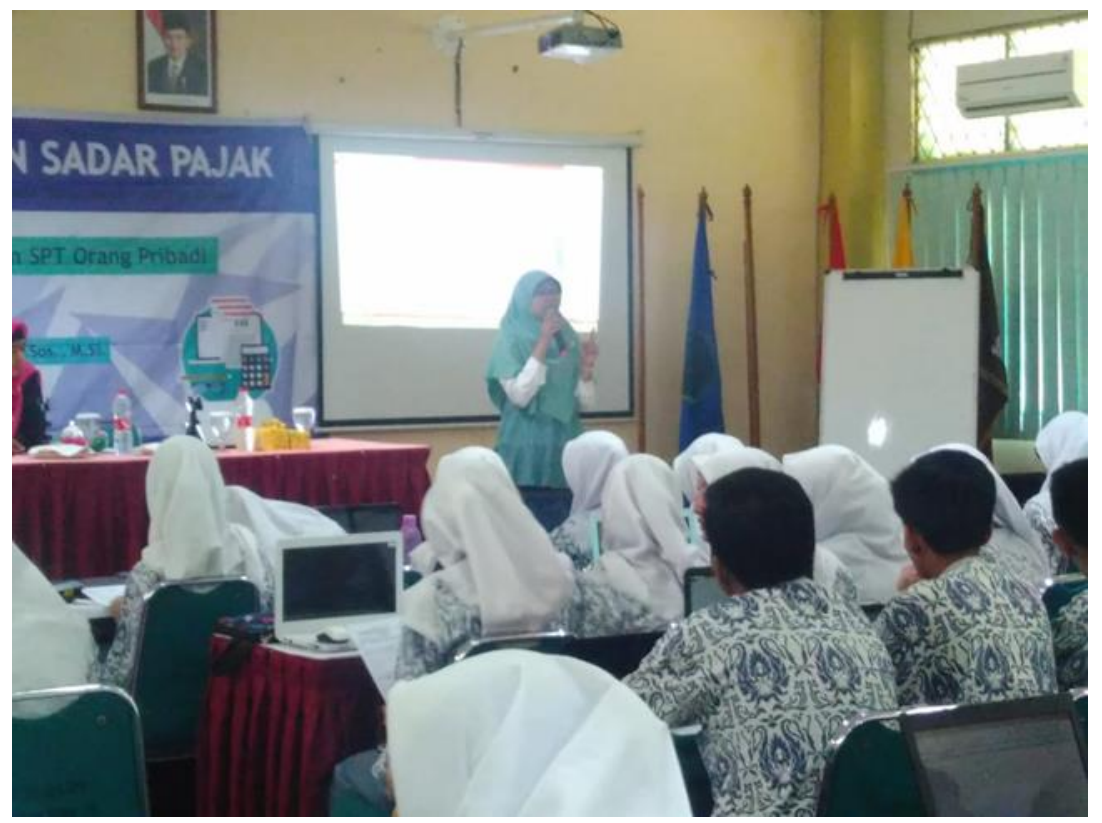

Gambar 3. Penyampaian Simulasi Pengisian SPT PPh Orang Pribadi oleh Notika Rahmi, S.AP., MA 
4. Latihan Penghitungan dan Pengisian SPT PPh Orang Pribadi

Peserta kegiatan workshop diberikan kesempatan untuk melakukan penghitungan dan pengsian SPT PPh Orang Pribadi seperti yang telah dicontohkan sebelumnya. Pertama yang dilakukan adalah melakukan penghitungan pajak terutang, kemudian dilanjutkan dengan menentukan jenis SPT yang akan digunakan dalam melaporkan pajak terutangnya. SPT diisi dimulai dari bagian lampiran paling terakhir dan dilanjutkan kebagian depannya dan seterusnya sampai ke bagian induk SPT.

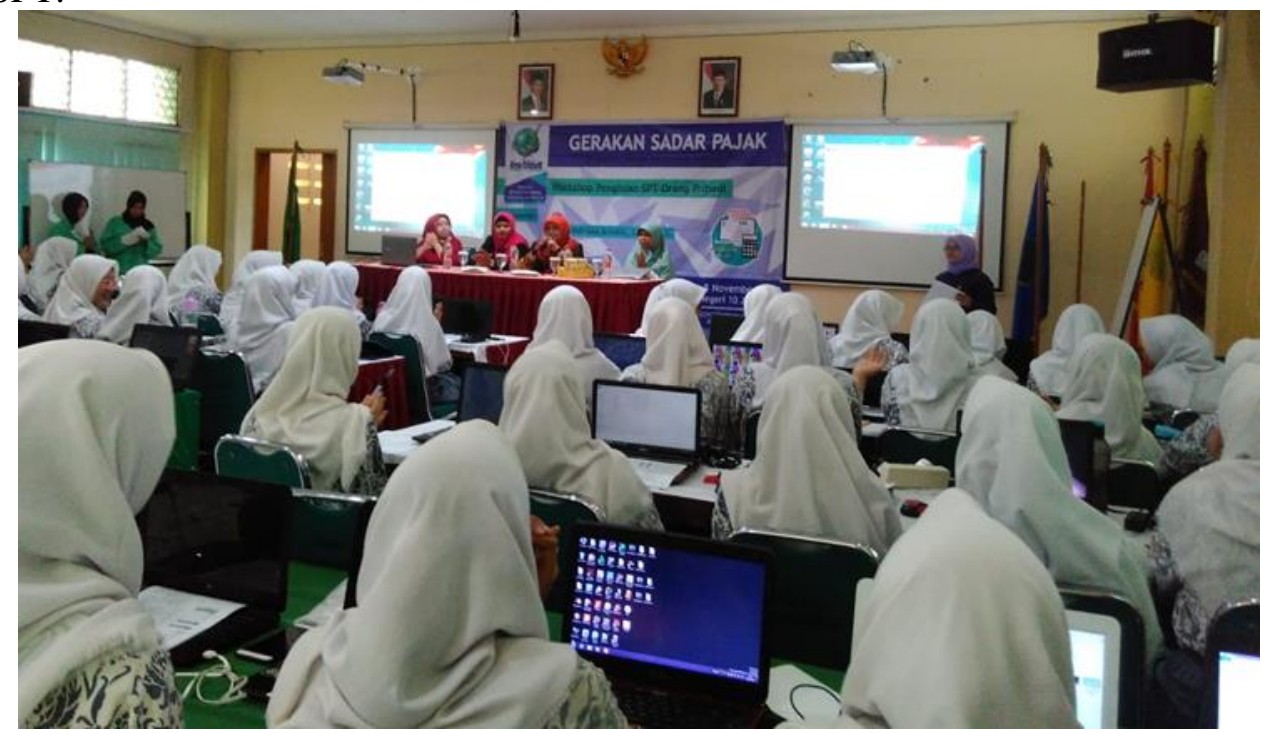

Gambar 4. Latihan Penghitungan dan Pengisian SPT PPh Orang Pribadi

Selanjutnya workshop dilanjutkan dengan sesi tanya jawab. Adapun pertanyaan peserta berupa:

1. Penentuan besarnya Penghasilan Tidak Kena Pajak

2. Perbedaan masing-masing jenis SPT PPh

3. Dampak ketidakpatuhan di bidang perpajakan

4. Syarat seseorang harus memperoleh NPWP

Hasil kegiatan PKM secara garis besar mencakup beberapa komponen yakni:

1. Keberhasilan target jumlah peserta pelatihan

2. Ketercapaian tujuan pelatihan

3. Ketercapaian target materi yang telah dilaksanakan

4. Kemampuan peserta dalam penguasaan materi

Target peserta workshop ialah seluruh siswa SMKN 10 Jakarta kelas XII Jurusan Akuntansi sejumlah 72 orang. Target peserta tercapai $100 \%$ yakni 72 orang siswa hadir. Angka tersebut menunjukkan bahwa kegiatan PKM dilihat dari jumlah peserta yang mengikuti dapat dikatakan berhasil.

Ketercapaian tujuan workshop secara umum sudah baik. Siswa/siswi dapat melakukan pengisian SPT PPh secara manual. Namun, karena adanya keterbatasan media pembelajaran maka siswa tidak dapat mempraktekkan $e$-filing.

Ketercapaian target materi sudah cukup baik. Peserta mampu menjawab pertanyaan-pertanyaan yang diajukan narasumber seusai pemberian materi.

Kemampuan peserta dapat dikatakan cukup baik dalam hal melakukan penghitungan dan pengisian SPT PPh Orang Pribadi. Namun demikian, pserta masih belum memiliki kemampuan untuk melakukan pengisian $e$-filing. 


\section{KESIMPULAN DAN SARAN}

\section{Kesimpulan}

Workshop Pengisian SPT PPh Orang Pribadi terselenggara dengan baik dan berjalan dengan lancar. Peserta mampu melakukan penghitungan dan pengisan SPT PPh Orang Pribadi secara manual. Adapun kekurangannya ialah tidak adanya media pembelajaran yakni $e$-filing berbentuk dummy untuk dapat dipraktekkan oleh peserta. Dari perspektif akademis kegiatan ini sangat efektif karena dapat menumbuhkan kesadaran perpajakan sejak dini.

Hambatan yang ditemui dalam pelaksanaan kegiatan ini adalah waktu yang singkat sehingga materi yang disampaikan harus dikelola menjadi lebih padat namun tetap dapat dimengerti dan poin yang hendak disampaikan dapat diterima dengan baik oleh peserta kegiatan.

\section{Saran}

Berdasarkan evaluasi yang telah dilakukan, berikut ialah saran kegiatan:

1. Bagi Dirjen Pajak, sebaiknya membuat aplikasi dummy e-filing agar masyarakat dapat berlatih melakukan pengisian SPT denga $e$-filing

2. Perlu adanya kegiatan lanjutan guna pembinaan kepatuhan pajak sejak dini

\section{DAFTAR PUSTAKA}

Cansavera. (2009). Perpajakan. Yogyakarta: Graha Ilmu.

Mardiasmo. (2011). Perpajakan. Yogyakarta: Andi.

Pohan, C. A. (2014). Pembahasan Komperhensif Perpajakan Indonesia Teori dan Kasus. Jakarta: Mitra Wacana Media.

Rahayu, S. K. (2010). Perpajakan Indonesia: Konsep dan Aspek Formal. Yogyakarta: Candi Gerbang Permai Blok R/6.

Resmi, S. (2017). Perpajakan: Teori dan Kasus Edisi 10. Jakarta: Salemba Empat 